GRASAS Y ACEITES 67 (1)

January-March 2016, e120

ISSN-L: 0017-3495

doi: http://dx.doi.org/10.3989/gya.0498151

\title{
Ultrafiltration-based degumming of crude rice bran oil using a polymer membrane
}

\author{
G.A.R. Sehn ${ }^{\bowtie}$, L.A.G. Gonçalves and C.C. Ming \\ Department of Food Technology, School of Food Engineering, University of Campinas. \\ Rua Monteiro Lobato 80, Zip code: 13083-862, Campinas, SP, Brazil \\ ${ }^{\square}$ Corresponding author: georgia.sehn@gmail.com
}

Submitted: 27 April 2015; Accepted: 21 September 2015

\begin{abstract}
SUMMARY: Membrane technology has been gaining momentum in industrial processes, especially in food technology. It is believed to simplify processes, reduce energy consumption, and eliminate pollutants. The objective was to study the performance of polyvinylidene fluoride (PVDF) and polyethersulfone (PES) polymeric membranes in the degumming of the miscella of crude rice bran oil by using a bench-scale tangential filtration module. In addition, oil miscella filtration techniques using hexane and anhydrous ethyl alcohol solvents were compared. All membranes showed the retention of phospholipids and high flow rates. However, the best performance was observed using the 50-kDa PVDF membrane in miscella hexane solvent, with a 95.5\% retention of the phosphorus concentration (by a factor of 1.4), resulting in a permeate with $29 \mathrm{mg} \cdot \mathrm{kg}^{-1}$ of phosphorus and an average flow rate of $48.1 \mathrm{~L} \cdot \mathrm{m}^{-2} \cdot \mathrm{h}^{-1}$. This technology can be used as a low-pollution, economical alternative for the de-gumming of crude rice bran oil, being effective in the removal of hydratable and non-hydratable phospholipids, resulting in oils with a low phosphorus content.
\end{abstract}

KEYWORDS: Crude rice bran oil; Phospholipids; Polymeric membranes; Ultrafiltration

RESUMEN: Desgomado de aceite de salvado de arroz crudo usando ultrafiltración con membrana polimérica. La tecnología de membrana ha ido ganando impulso en los procesos industriales, especialmente en tecnología de los alimentos. Se piensa que simplifica los procesos, reduce el consumo de energía, y elimina contaminantes. El objetivo fué estudiar el rendimiento de las membranas poliméricas de fluoruro de polivinilo (PVDF) y poliétersulfona (PES) en el desgomado de miscelas de aceite de salvado de arroz crudo, mediante el uso de un módulo de filtración de escalado tangencial. Además, se compararon las técnicas de filtración de miscelas de aceite, utilizando como disolventes hexano y alcohol etílico anhidro. Todas las membranas mostraron retención de los fosfolípidos y altas tasas de flujo. Sin embargo, se observó un mejor rendimiento usando la membrana de PVDF de 50-kDa con hexano como disolvente, con una retención del 95,5\% de la concentración de fósforo (por un factor de 1,4), dando como resultado un permeado con $29 \mathrm{mg} \cdot \mathrm{kg}^{-1}$ de fósforo y un promedio tasa de $48,1 \mathrm{~L} \cdot \mathrm{m}^{-2} \cdot \mathrm{h}^{-1}$ de fluido. Esta tecnología se puede considerar como de baja contaminación y una alternativa económica para el desgomado de aceite de salvado de arroz crudo, siendo eficaz en la eliminación de los fosfolípidos hidratables y no hidratables, resultando unos aceites con un bajo contenido en fósforo.

PALABRAS CLAVE: Aceite de salvado de arroz crudo; Fosfolipidos; Membranas poliméricas; Ultrafiltración

Citation/Cómo citar este artículo: Sehn GAR, Gonçalves LAG, Ming CC. 2016. Ultrafiltration-based degumming of crude rice bran oil using a polymer membrane. Grasas Aceites 67 (1): e120. doi: http://dx.doi.org/10.3989/gya.0498151.

Copyright: (C) 2016 CSIC. This is an open-access article distributed under the terms of the Creative Commons Attribution-Non Commercial (by-nc) Spain 3.0 Licence. 


\section{INTRODUCTION}

Degumming is a refining step, wherein the phospholipids are removed. The presence of large quantities of phospholipids in oil leads to a dark coloration; in addition, phospholipids act as emulsifiers, leading to a loss in neutral oils and resulting in a low quality product (Erickson, 1995; Manjula and Subramaniam, 2006).

The conventional oil refinement process is characterized by high energy, water, and chemical product requirements, loss in neutral oil and nutrients, and a high rate of effluent production (Subramanian et al., 2001; Roy et al., 2014). In contrast, the use of membranes during processing has been shown to simplify the process. The membrane filtration process involves the separation of components of a pressurized liquid through a membrane; this method allows for the separation of compounds using the differences in size, molecular weight, and pressure as the driving force, without the use of chemicals (Frieldlander and Rickes1966; Cheryan, 1998; Coutinho et al., 2009).

The similar molecular weights of triacylglycerols (900 Da) and phospholipids (700 Da) could complicate the membrane-based separation of these components. However, phospholipids have some specific features that could assist in their separation; they are natural surfactants and express hydrophilic and hydrophobic groups that are capable of forming micelle under non-aqueous conditions (Ochoa et al., 2001).

Pardun (1988) described micelle as the structures formed upon aggregation of amphoteric molecules. Micelle formation occurs when the concentration of monomers reaches a certain level, known as the critical micelle concentration. Its size is based on the molecular weight of the component monomers; it is also related to the molar weight of the phospholipids and the total number of component monomers. Hexanol is known to form a micelle with a molecular weight of 22,000 Da and a dielectric constant of $13 \mathrm{D}$, while anhydrous ethyl alcohol is believed to form a micelle with a molar weight of 7,100 Da and a dielectric constant of $24 \mathrm{D}$. When hydrated (ethanol 93.4\%), the molecular weight and dielectric constant of this micelle decreased and increased to $770 \mathrm{Da}$ and $29 \mathrm{D}$, respectively (Pardun, 1988).

Hexane solvents have a dielectric constant of 1.88 D (Rydberg et al., 1992); phospholipid micelle formation in these solvents commences with a number of monomers of approximately 20,000 Da with high aggregation levels. This enables the separation of triacylglycerols using membranes with adequate selectivity, wherein the phospholipid micelle cannot permeate through the pores of the ultrafiltration membranes (Subramanian and Nakajima, 1997; Lin et al., 1997; Ochoa et al., 2001; Pagliero et al., 2001).
The interaction of the solvent with the membranes may result in expansion (swelling), lamination, or dissolution of the membrane; this would subsequently cause structural changes to the membrane, leading to changes in the separation properties and reduced mechanical resistance to pressure (Tsui and Cheryan, 2004).

The solvent flow through the polymeric membrane mainly depends on solvent polarity; therefore, the solvent flow is decreased in hydrophobic membranes and increased in hydrophilic membranes, as the polarity in organic solvents is closely related to surface tension. Polyvinylidene fluoride (PVDF) membranes were observed to possess greater stability towards hexane than polyethersulfone (PES) membranes in the studies conducted by Ochoa et al. (2001) and Araki et al. (2010). Similarly, Iwama (1987) reported that the PVDF polymer is chemically and physically resistant to the hexane solvent, especially at high temperatures $\left(40-60{ }^{\circ} \mathrm{C}\right)$. Araki et al. (2010) revealed that PES membranes allowed higher flow of the ethanol solvent than of water and hexane.

The main aim of this project was to study the performance of PVDF and PES polymer membranes in the degumming of crude rice bran oil using a tangential filtration module bench, and to compare our results to those of previous studies.

\section{MATERIALS AND METHODS}

\subsection{Materials}

The ultrafiltration unit (Figure 1) was fed in each of the experiments with $30 \%$ miscella of crude rice bran oil (pressing) in solvent $(\mathrm{w} / \mathrm{w})$, obtained from Irgovel (Pelotas, Brazil). Hexane and anhydrous ethyl alcohol (99.8\% purity grade each), purchased from Ecibra (Santo Amaro, Brazil), was used to migrate through PVDF and PES membranes, respectively.

\subsection{Membranes}

The following commercially available flat polymeric membranes were used in this study: PVDF with a $0.05 \mu \mathrm{m}$ pore size filter DBD (Mauá, Brazil) denoted as $50-\mathrm{kDa}$ PVDF, PVDF with a $0.075 \mu \mathrm{m}$ pore size Nadir $^{\circledR}$ (Wiesbaden, Germany) denoted as 75-kDa PVDF, and PES with a pore size of $0.005 \mu \mathrm{m}$ Nadir $^{\circledR}$ (Wiesbaden, Germany) denoted as 5-kDa PES.

The membranes were cut into $7 \mathrm{~cm} \times 11 \mathrm{~cm}$ rectangles, covering a permeation area of $0.0077 \mathrm{~m}^{2}$ and conditioned in the solvents used in the ultrafiltration process (hexane for PVDF and anhydrous ethyl alcohol for PES). The membranes were kept immersed in the solvent for $24 \mathrm{~h}$ at room temperature prior to use (Kesting, 1985). New membrane cutouts were used for each trial. 


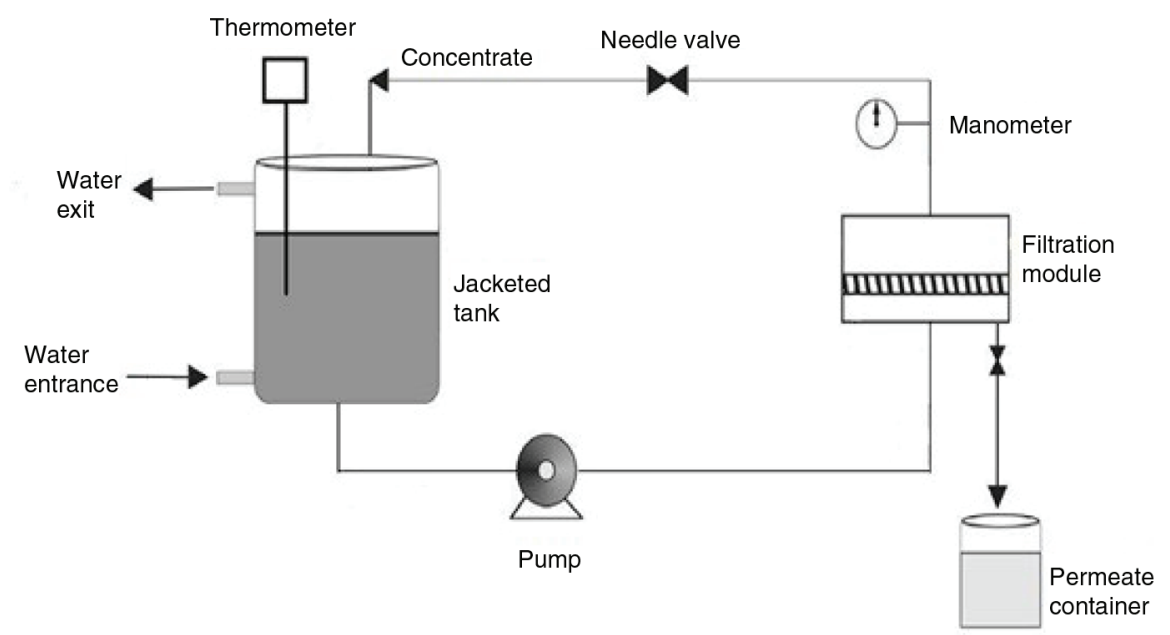

FIGURE 1. Schematic diagram of the ultrafiltration cell used to test the polymeric membranes.

\subsection{Methods}

\subsubsection{Characterization of the raw material}

The crude rice bran oil was characterized based on the peroxide index, calculated iodine index, and the calculated saponification index, according to the protocols $\mathrm{Cd} 8 \mathrm{~b}-90, \mathrm{Cd} \mathrm{1c-85}$, and $\mathrm{Cd}$ 3a-94, detailed by the AOCS (2009). Phosphorus content was analyzed as per the AOCS Ca 19-86 method (2009), adapted from a method detailed by Antoniassi and Esteves (1995). The fatty acid composition was determined by capillary gas chromatography (CGC Agilent 6850 Series GC System), equipped with a capillary column Agilent DB-23 ( $50 \%$ cyanopropyl-methylpolysiloxane) with the following dimensions: $60 \mathrm{~m} \times 0.25 \mathrm{~mm}$ internal diameter $\times 0.25 \mu \mathrm{m}$ film, according to the AOCS Ce $1 \mathrm{f}-96$ method (2009). The operating conditions were set as follows: column flow $=1.0 \mathrm{~mL} \cdot \mathrm{min}^{-1}$, linear velocity $=24 \mathrm{~cm} \cdot \mathrm{s}^{-1}$, detector temperature $=280{ }^{\circ} \mathrm{C}$, injector temperature $=250{ }^{\circ} \mathrm{C}$, oven temperature $=110-215^{\circ} \mathrm{C}$ $\left(5{ }^{\circ} \mathrm{C} \cdot \mathrm{min}^{-1} ; 215{ }^{\circ} \mathrm{C}-24 \mathrm{~min}\right)$, carrier gas-helium, injection volume $=1.0 \mu \mathrm{L}$. The standard used was the GLC Reference Standard (68 th, Lot $n^{\circ}$ : JA13-V; Nu-Chek Prep, Inc.). The esterification step was performed according to the method detailed by Hartman and Lago (1973).

\subsubsection{Filtration methodology}

A stainless steel 2 L Invict (Campinas, Brazil) tangential-flow filtration module bench-scale was coupled to support the flat rectangular $(7 \mathrm{~cm} \times 11 \mathrm{~cm}$; permeation area $0.0077 \mathrm{~m}^{2}$ ) polymer membrane. The process temperature and tangential velocity were set to $40^{\circ} \mathrm{C}$ and $0.20 \mathrm{~ms}^{-1}$, respectively, for the miscella in hexane, and $40{ }^{\circ} \mathrm{C}$ and $0.24 \mathrm{~m} \cdot \mathrm{s}^{-1}$, respectively, for the miscella in anhydrous ethyl alcohol because of equipment limitations. The tank was fed with $1 \mathrm{~kg}$ of miscella; the temperature was stabilized to the following working conditions: the pressure was set at 5 bar by closing the needle type valve of a Nuovafima (Belenzinho, Brazil) manometer with a scale of 0 to $7 \mathrm{kgf} \cdot \mathrm{cm}^{-2}$, the tangential velocity was set using the WEG (Jaraguá do Sul, Brazil) frequency inverter pump, and a Hydra-Cell (Minneapolis, United States of America) electrically driven diaphragm pump was started. The permeate was collected in a graduated cylinder, where the cumulative volume was recorded as a function of time in order to obtain a concentration factor (CF) of 1.4 by weight. For all experiments new membranes were used.

The tangential velocity (TV) was calculated using Equation 1, where Ae is the outflow area $\left(0.00007 \mathrm{~m}^{2}\right)$ and $\mathrm{v}$ is the flow rate $\left(\mathrm{m}^{3} \cdot \mathrm{s}^{-1}\right)$.

$$
T V\left(m . s^{-1}\right)=\frac{v\left(m^{3} \cdot s^{-1}\right)}{A_{e}\left(m^{2}\right)}
$$

\subsubsection{Calculation of the performance evaluation parameters of the ultrafiltration process $(U F)$}

The membrane performance was expressed in terms of the permeate flow, phosphorus retention coefficient, and concentration factor. These were calculated using the following equations:

The permeate flow $(\mathrm{J})$ was calculated using Equation 2, where $\mathrm{V}$ is the amount of permeate in volume, $\mathrm{A}$ is the permeation area, and $\mathrm{t}$ is time:

$J\left(\frac{L}{m^{2} \cdot h}\right)=\frac{V(L)}{A\left(m^{2}\right) \cdot t(h)}$ 
The retention coefficient $(\% \mathrm{R})$ of phosphorus was calculated in percentage using Equation 3, where Cfeed and $\mathrm{Cp}$ are the phosphorus concentrations in the feed and permeate, respectively, under a given CF:

$\% R=\left(\frac{1-C p}{C \text { feed }}\right) \times 100$

The Concentrantion Factor was calculated using Equation 4, where Mal and Mret denote the weight of the miscella in the feed and the final retentive weight, respectively.

$C F=\frac{\text { Mal }}{\text { Mret }}$

\subsubsection{Morphological and elemental analysis of polymeric membranes by scanning electron microscopy (SEM) and energy dispersive system $(E D S)$}

The central portion of the unused membranes and the membranes used for ultrafiltration was cut into a $1 \mathrm{~cm} \times 1 \mathrm{~cm}$ square. The surfaces of the unused and post-use membranes were analyzed by high vacuum scanning electron microscopy. For this purpose, a TM 3000 microscope Hitachi (Tokyo, Japan) was used, with a magnification of $15 \times$ to $30000 \times$, and an accelerating voltage of $15 \mathrm{kV}$ (Analysis mode), coupled to a back scattered electron detector (Swift ED 3000; Hitachi) composed of a high sensitivity semiconductor (with a resolution of $148 \mathrm{eV}$ or more in $\mathrm{MnK}$ ), which analyzes the elements from boron to uranium.

\section{RESULTS AND DISCUSSION}

\subsection{Characterization of raw materials}

The fatty acid composition of crude rice bran oil (Table 1) showed the presence of approximately $23 \%$ saturated fatty acids, $39 \%$ monounsaturated fatty acids, and $37 \%$ polyunsaturated fatty acids. According to Orthoefer (2005) and Pestana et al. (2008), rice bran oil, which is composed of $90 \%$ triacylglycerols, predominantly contains palmitic, oleic, and linoleic fatty acids.

The iodine index measurement reflected the presence of double bonds of fatty acids (Lawson, 1995). The iodine index of rice bran oil was 101 determined to be $\operatorname{cgI}_{2} \cdot 100 \mathrm{~g}^{-1}$; this result was within the range (99-108) cited by Orthoefer (2005), and displays its high degree of unsaturation.

Saravanan et al. (2006) observed a phosphorus content of $499 \mathrm{mg} \cdot \mathrm{kg}^{-1}$ in the rice bran oil tested in their study, which was lower than that seen in this study $\left(640.5 \mathrm{mg} \cdot \mathrm{kg}^{-1}\right)$.
TABLE 1. Characterization of crude rice bran oil

\begin{tabular}{|c|c|}
\hline Composition of FattyAcids & $\%$ \\
\hline $\mathrm{C} 14: 0$ & 0.30 \\
\hline $\mathrm{C} 16: 0$ & 19.20 \\
\hline C16:1 & 0.20 \\
\hline C18:0 & 2.20 \\
\hline C18:1 & 37.20 \\
\hline $\mathrm{C} 18: 2$ & 36.50 \\
\hline C18:3 & 2.00 \\
\hline C20:0 & 1.00 \\
\hline $\mathrm{C} 20: 1$ & 0.50 \\
\hline $\mathrm{C} 22: 0$ & 0.30 \\
\hline $\mathrm{C} 24: 0$ & 0.60 \\
\hline Calculated iodine index $\left(\mathrm{cg} \mathrm{I}_{2} \cdot 100 \mathrm{~g}^{-1}\right)$ & 101 \\
\hline Calculated saponification index $\left(\mathrm{mg} \mathrm{KOH} \cdot \mathrm{g}^{-1}\right)$ & 193 \\
\hline Peroxide value $\left(\mathrm{meq} \cdot \mathrm{kg}^{-1}\right)$ & 9.8 \\
\hline Phosphorus content $\left(\mathrm{mg} \cdot \mathrm{kg}^{-1}\right)$ & 640.5 \\
\hline
\end{tabular}

All values were determined in duplicate.

\subsection{Degumming of crude rice bran oil in the ultrafiltration unit}

Approximately $95.5 \%$ of the phospholipid content of the crude rice bran oil was retained in the form of miscella using the 50-kDa PVDF membrane (hexane solvent) (Table 2). The residual phosphorous values in the permeate reached up to $29 \mathrm{mg} \cdot \mathrm{kg}^{-1}$ of phosphorus, with the removal of both hydratable and non-hydratable phospholipids. The 75-kDa PVDF membrane, on the other hand, showed intermediate results, with the retention of $82.3 \%$ phospholipids. The 5-kDa PES membrane showed a phospholipid retention rate of $62 \%$ in the miscella formed with the use of anhydrous ethyl alcohol as the solvent. The difference in the two types of solvent used during miscella formulation in the crude rice bran oil was that the PVDF membrane is hydrophobic, whereas the PES membrane is hydrophilic.

Manjula and Subramanian (2009) found retentions of 95.1 and $98.8 \%$ of phospholipids on two different types of crude rice bran oils, respectively, using a nonporous polymeric composite hydrophobic membrane (NTGS 2200) diluted 1:3 (oil:hexane).

According to Yang et al. (2001), the nominal molecular weight cut-off for polymeric membranes specified by the manufacturer, is valid only for predicting the rejection in aqueous solutions. The retention of solutes in organic solvents, for molecules of the same molar weight, or even a single molecule, is unpredictable and depends on the specific solvent. If the interaction between the solvent and polymer is strong, swelling may occur, leading to the contraction of the membrane pores (Paul and 
TABLE 2. Ultrafiltration of crude rice bran oil miscella as a function of the material and porosity of the polymeric membrane, to a concentration factor of 1.4 (initial oil contained $640 \mathrm{mg} \cdot \mathrm{kg}^{-1}$ phosphorus)

\begin{tabular}{llclccc}
\hline Membrane & Porosity & $\begin{array}{c}\text { Pressure } \\
\text { (bar) }\end{array}$ & \multicolumn{1}{c}{ Solvent } & $\begin{array}{c}\mathbf{J} \\
\left(\mathbf{L} \cdot \mathbf{m}^{-2} \cdot \mathbf{h}^{-1} \mathbf{)}\right.\end{array}$ & $\begin{array}{c}\text { \% R R } \\
\begin{array}{c}\text { Residual P in the } \\
\text { permeate }\left(\mathbf{m g} \cdot \mathbf{k g}^{-1}\right)^{*}\end{array}\end{array}$ \\
\hline 50-kDa PVDF & $0.05 \mu \mathrm{m}$ & 5 & Hexane & 48.1 & 95.5 & $29 \pm 5$ \\
75-kDa PVDF & $0.075 \mu \mathrm{m}$ & 5 & Hexane & 55.8 & 82.3 & $113 \pm 11$ \\
5-kDa PES & $0.005 \mu \mathrm{m}$ & 5 & AnhydrousEthyl Alcohol & 49.5 & 62.0 & $243 \pm 15$ \\
\hline
\end{tabular}

*All values were determined in triplicate; $\mathrm{J}=$ accumulated average flow of permeate; $\% \mathrm{R}=$ Retention of phospholipids; $\mathrm{P}=$ Phosphorus

Lima, 1970; Tsui and Cheryan, 2004). This behavior can be observed in the 50-kDa PVDF membranes in the presence of hexane solvent and justifies the higher retention of phospholipids in this membrane. In addition, the molecular weight of phospholipids is approximately $700 \mathrm{Da}$ and that of triglycerides is $900 \mathrm{Da}$; upon addition of the solvent, because of the formation of phospholipid micelle composed of approximately 20,000 Da monomers, the membranes reject the phospholipids and permeate the triglycerides (Subramanian and Nakajima, 1997).

The 50-kDa PVDF, 75-kDa PVDF, and 5-kDa PES polymeric membranes showed the same flow behavior of up to $1.4 \mathrm{CF}$ at 5 bar pressure (Figure 2). A sharp decline in flow was observed during the first few minutes, followed by a decrease in drop rate and a tendency to stabilize; this was similar to the flow behavior observed by Pagliero et al. (2007). This behavior can be attributed to the retention of the phospholipid agglomerates in the membrane pores, and the high wax content present in the rice bran oil $(5.3$ to $6.2 \%)$, which may lead to an increase in the deposited layer on the membrane surface and result in clogged pores (Orthoefer, 2005; Pagliero et al., 2007).
According to Kaimal et al. (2002), another important factor that could negatively affect the processing of crude rice bran oil is the high presence of phosphorous-containing glycolipids; the glycolipid content in rice bran oil is very high (approximately 6\%). The presence of these compounds may affect the color and quality of the final product in addition to hindering phospholipid removal, which is important for the proper processing of rice bran oil.

The initial flow through the 75-kDa PVDF and 5-kDa PES membranes (at 5 bar pressure) was higher than that observed through the 50-kDa PVDF membrane. However, a sharp decline in the flow was observed because of the increase in concentration polarization throughout the process, which in turn accelerated the formation of the polarized layer.

The 75-kDa PVDF membrane displayed a high average flow of $55.8 \mathrm{~L} \cdot \mathrm{m}^{-2} \cdot \mathrm{h}^{-1}$ (Table 2), because of its larger pore diameter, and intermediate results $(82.3 \%)$ in the retention of phospholipids, demonstrating a viable alternative for use in the degumming of rice bran oil. On the other hand, the $5-\mathrm{kDa}$ PES membrane showed $62 \%$ phospholipid retention in miscella form (using anhydrous ethyl alcohol as a solvent), and required a long time to reach a $\mathrm{CF}$

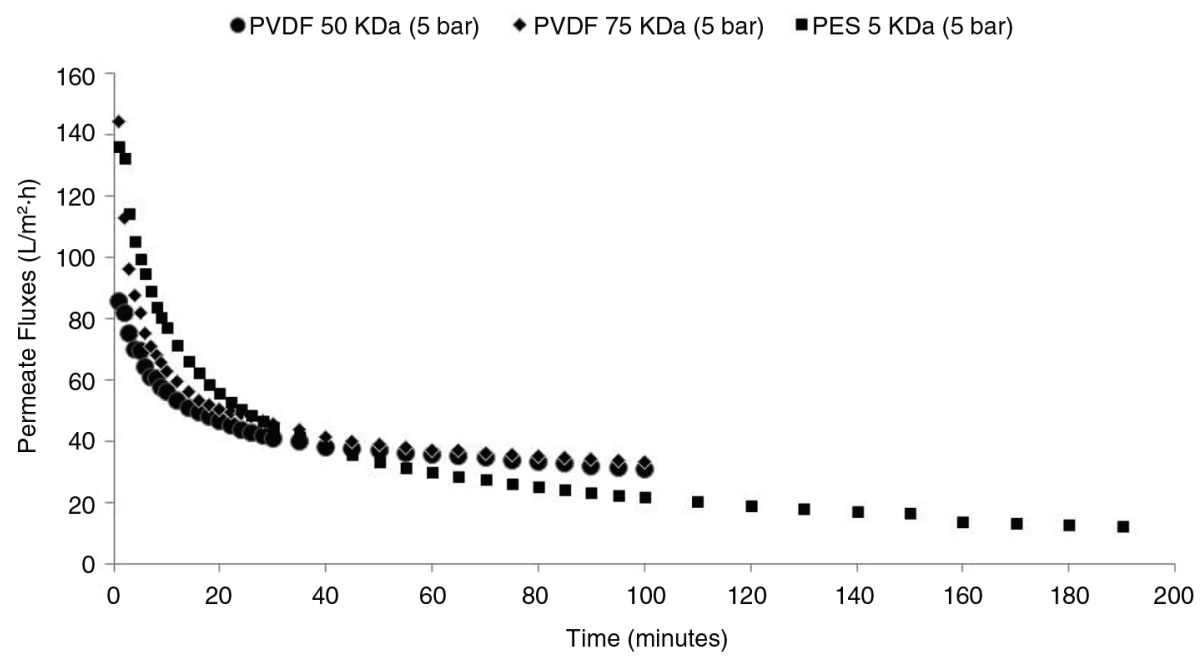

FIGURE 2. Ultrafiltration of crude rice bran oil miscella using PVDF (hexane solvent) and PES (anhydrous ethyl alcohol solvent) polymeric membranes with differing porosities, to a CF of 1.4. 
of 1.4. Ochoa et al. (2001) observed similar results in experiments using $10-\mathrm{kDa}$ PES membranes and crude soybean oil. Triacylglycerols have low solubility in ethanol at temperatures between $25^{\circ} \mathrm{C}$ and $65^{\circ} \mathrm{C}$ (Kumar and Bhowmick, 1996; Freitas et al., 2007) which hinders the passage of miscella through the membrane, necessitating a longer time to reach a $\mathrm{CF}$ of 1.4 , in addition to a sharp decrease in the flow and the probable onset of pore obstruction. The flow rates encountered in this study can be considered higher than those observed by Manjula and Subramanian (2009), who used non-porous membranes $\left(2.04 \mathrm{~kg} \cdot \mathrm{m}^{-2} \cdot \mathrm{h}^{-1}\right)$ for the de-gumming of crude rice bran oil.

\subsection{SEM and EDS analyses}

Figure 3 shows the surface microstructure of the 50-kDa PVDF, 75-kDa PVDF, and 5-kDa PES membranes at 5 bar pressure, analyzed by SEM before and after the ultrafiltration process. Both types of intact membranes displayed the absence of material attached to their surface, facilitating the observation of pore surface definition and distribution. All PVDF and PES polymeric membranes evaluated after miscella permeation displayed visual changes on the surface as a result of solute deposition; regions of greater deposition, as well as flatter regions with lower deposition were observed.

The EDS analysis of the intact $50-\mathrm{kDa}$ and 75-kDa PVDF polymeric membranes revealed the presence of carbon, fluorine, and oxygen (Table 3), compounds present in the membrane structure. None of the analyzed membranes showed any significant morphological changes resulting from the filtration process.

Following permeation, the $50-\mathrm{kDa}$ PVDF and 75-kDa PVDF membranes showed small quantities of phosphorus, $0.12 \%$ calcium and $0.11 \%$ magnesium;
(A)

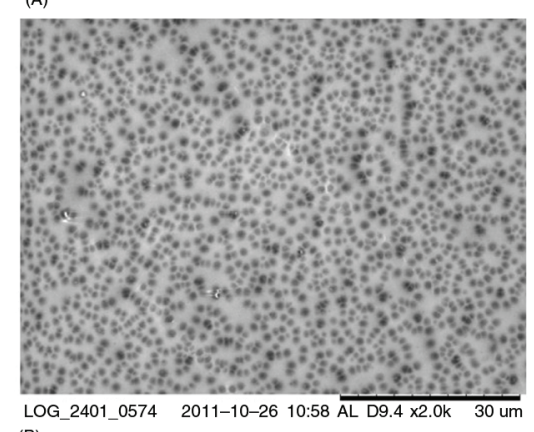

(B)

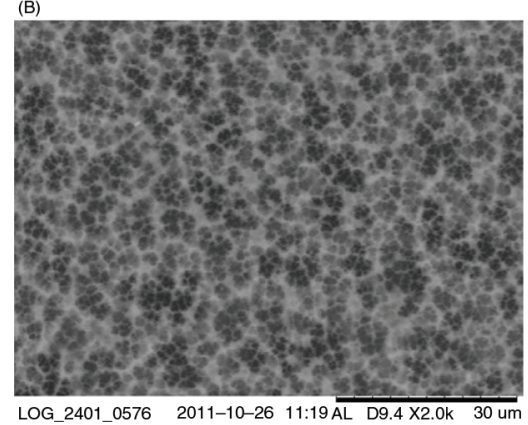

LOG_2401_0576 2011-10-26 11:19AL D9.4 X2.0k 30 um (C)

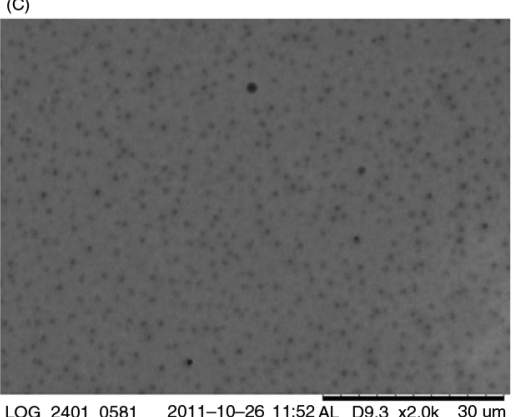

(D)

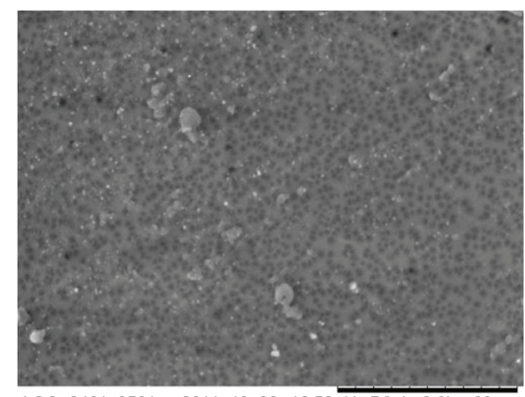

LOG_2401_0591 2011-10-26 12:58 AL D9.4 x2.0k $30 \mathrm{um}$ (E)

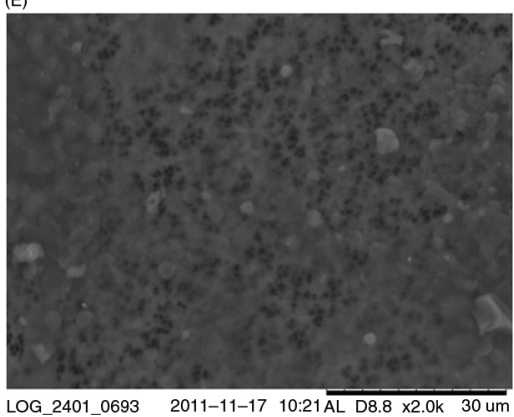

LOG_2

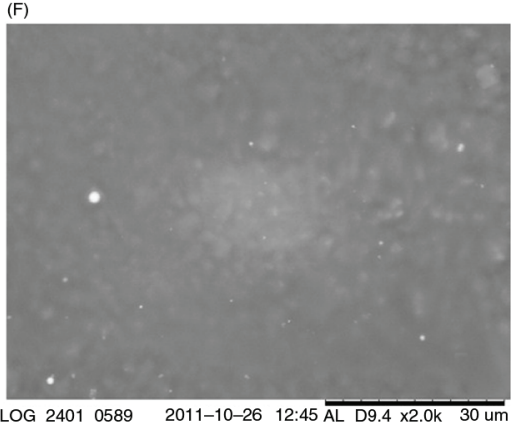

FIGURE 3. Photomicrographs of intact 50-kDa PVDF (A), 75-kDa PVDF (B), and 5-kDa PES (C) membranes, and 50-kDa PVDF (D), 75-kDa PVDF (E), and 5-kDa PES (F) membranes after ultrafiltration, with a 2000×increase in magnification. 
TABLE 3. Results of the energy dispersive system (EDS) analysis of intact polymeric membranes, and membranes used in the ultrafiltration process

\begin{tabular}{|c|c|c|c|c|c|c|}
\hline \multirow[b]{2}{*}{ Element } & \multicolumn{3}{|c|}{ Intact membrane } & \multicolumn{3}{|c|}{ Membrane after ultrafiltration } \\
\hline & $\begin{array}{c}\text { 50-kDa } \\
\text { PVDF (\%) }\end{array}$ & $\begin{array}{c}\text { 75-kDa } \\
\text { PVDF (\%) }\end{array}$ & $\begin{array}{c}\text { 5-kDa } \\
\text { PES (\%) }\end{array}$ & $\begin{array}{c}\text { 50-kDa } \\
\text { PVDF (\%) }\end{array}$ & $\begin{array}{c}\text { 75-kDa } \\
\text { PVDF (\%) } \\
\end{array}$ & $\begin{array}{c}\text { 5-kDa } \\
\text { PES (\%) }\end{array}$ \\
\hline Carbon & 44.97 & 53.71 & 68.87 & 67.72 & 71.23 & 84.90 \\
\hline Oxygen & 13.60 & 18.43 & 21.44 & 7.62 & 13.59 & 12.11 \\
\hline Fluorine & 41.43 & 27.86 & - & 24.38 & 14.71 & - \\
\hline Sodium & - & - & 0.83 & - & - & - \\
\hline Silicon & - & - & 0.08 & - & - & 0.25 \\
\hline Sulfur & - & - & 7.90 & - & - & 2.62 \\
\hline Chlorine & - & - & 0.60 & - & - & - \\
\hline Potassium & - & - & 0.28 & - & - & - \\
\hline Phosphorus & - & - & - & 0.16 & 0.36 & 0.12 \\
\hline Calcium & - & - & - & 0.12 & - & - \\
\hline Magnesium & - & - & - & - & 0.11 & - \\
\hline
\end{tabular}

these compounds were possibly released from nonhydratable phospholipids present in the crude rice bran oil, which remained adhered to the membrane surface.

The 5-kDa PES membrane (after permeation) did not show the presence of chlorine or potassium, which are originally present in small quantities. However, a small quantity of phosphorus $(0.12 \%)$ was detected, which might have been released from the phospholipids during the de-gumming of crude rice bran oil.

\section{CONCLUSION}

The commercial flat polymeric membrane prepared using PVDF (50-kDa molecular weight cut-off) showed the best retention of phospholipid miscella present in the crude rice bran oil (obtained using a hexane solvent), with a retention value of $95.5 \%$. The obtained permeate had a phosphorus content of $29 \mathrm{mg} \cdot \mathrm{kg}^{-1}$, and was associated with a flow rate of $48.1 \mathrm{~L} \cdot \mathrm{m}^{-2} \cdot \mathrm{h}^{-1}$. The 5 -kDa PES polymer membrane showed interesting results, with respect to the retention of phospholipids $(62 \%)$ and the permeate flow $\left(49.5 \mathrm{~L} \cdot \mathrm{m}^{-2} \cdot \mathrm{h}^{-1}\right)$, for crude rice bran oil miscella (obtained using anhydrous ethyl alcohol). The degumming of crude oils using the membrane separation process shows better viability, with regard to the rate of phospholipid retention. SEM and EDS analyses are indispensable tools for the evaluation of the microstructure of the polymeric membrane surface before and after the permeation process.

\section{ACKNOWLEDGEMENTS}

The authors would like to thank Capes, CNPq and FAPESP.

\section{REFERENCES}

American Oil Chemists' Society (2009) Official methods and recommended practices of the American Oil Chemists' Society. 6th ed. Champaign.

Antoniassi R, Esteves W. 1995. Otimização da metodologia da AOCS (Official Method Ca 12 55) para determinação de conteúdo de fósforo em óleos, in Latin America Congress and Exhibit on Fats Processing, VI, Campinas. Proceedings, pp. 211-215.

Araki MS, Coutinho CM, Goncalves LAG, Viotto LA.2010. Solvent permeability in commercial ultrafiltration polymeric membranes and evaluation of the structural and chemical stability towards hexane. Sep. Purif. Technol. 71, 13-21. http://dx.doi.org/10.1016/j.seppur.2009.10.005.

Cheryan M. 1998. Ultrafiltration and microfiltration handbook. Lancaster, Technomic Publ., USA.

Coutinho CM, Chiu CM, Basso RC, Ribeiro APB, Gonçalves LAG, Viotto LA. 2009. State of art of the application of membrane technology to vegetable oils: A review. Food Res. Int. 42, 536-550. http://dx.doi.org/10.1016/j.foodres. 2009.02 .010 .

Erickson DR. 1995. Degumming and Lecithin Processing and Utilization, in Erickson DR (Ed) Practical Handbook of Soybean Processing and Utilization. AOCS Press, Champaign, pp. $174-183$.

Freitas SP, Silva OF, Miranda IC, Coelho MAS. 2007. Extração e fracionamento simultâneo do óleo da Castanha do Brasil com etanol. Ciênc. Tecnol. Aliment. 27, 14-17.

Frieldlander HZ, Rickes RN. 1966. Membrane separation processes. Chem. Eng. 73, 111-116.

Hartman L, Lago R. 1973. Rapid preparation of fatty acid methyl esters from lipids. Lab Pract. 22, 475-476.

Iwama A. 1987. New process for purifying soybean oil by membrane separation and an economical evaluation of process. J. Am. Oil Chem. 64, 244-250.

Kaimal TNB, Vali SR, Rao BVSK, Chakrabarti PP, Vijayalakshmi P, Kale V, Rani KNP, Rajamma O, Bhaskar PS, Rao TC. 2002. Origin of problems encountered in rice bran oil processing. Eur. J. Lipid Sci. Technol. 104, 203-211.

Kesting RE. 1985. Synthetic Polymeric Membranes: a Structural Perspective. 2nd ed, Wiley-Interscience Publication, New York, USA.

Kumar NSK, Bhowmick DN. 1996. Separation of Fatty Acids/ Triacylglycerol by membranes. J. Am. Oil Chem. 73, 399-401.

Lawson H. 1995. Food oils and fats: technology, utilization and nutrition. Chapman \& Hall, New York, USA. 
Lin L, Rhee K, Koseoglu SS. 1997. Bench-scale membrane degumming of crude vegetable oil: process optimization. J. Membrane Sci. 134, 101-108. http://dx.doi.org/10.1016/ S0376-7388(97)00098-7.

Manjula S, Subramanian R. 2006. Membrane Technology in degumming, dewaxing, deacidifying, and decolorizing edible oils. Crit. Rev. Food Sci. 46, 569-592. http://dx.doi.org/ $10.1080 / 10408390500357746$.

Manjula S, Subramanian R. 2009. Simultaneous degumming, dewaxing and decolorizing crude rice bran oil using nonporous membranes. Sep. Purif. Technol. 66, 223-228. http:// dx.doi.org/10.1016/j.seppur.2009.01.004.

Ochoa N, Pagliero C, Marchese J, Mattea M. 2001. Ultrafiltration of vegetable oils: degumming by polymeric membrane. Sep. Purif. Technol. 22-23, 417-422. http://dx.doi.org/10.1016/ S1383-5866(00)00178-7.

Orthoefer FT. 2005. Rice bran oil, in Shahidi F (Ed.) Bailey's industrial oil \& fat products, 6thed, John Wiley \& sons, New Jersey, pp. 465-489.

Pagliero C, Mattea M, Ochoa N, Marchese J. 2007. Fouling of polymeric membranes during degumming of crude sunflower and soybean oil. J. Food Eng. 78, 194-197. http:// dx.doi.org/10.1016/j.jfoodeng.2005.09.015.

Pagliero C, Ochoa N, Marchese J, Mattea M. 2001. Degumming of crude soybean oil by ultrafiltration using polymeric membranes. J. Am. Oil Chem. 78, 793-796.

Pardun H. 1988. Die Pflanzenlecithine: Gewinnung, Eigenschaften, Verarbeitung und Anwendungpflanzlicher Phosphatidpräparate, Hafen-Mühlen-Werke, Augsburg, GER.

Paul DR, Lima OME. 1970. The mecanism of liquid transport through highly swollen polymeric membranes. J. Appl.
Polym. Sci. 15, 2199-2210. http://dx.doi.org/10.1002/app. 1971.070150912.

Pestana VR, Mendonça CRB, Zambiazi RC. 2008. Farelo de arroz: características, benefícios à saúdee aplicações. $B$ do CEPPA 26, 29-40.

Roy B, Dey S, Sahoo GC, Roy SN, Bandyopadhyay S. 2014. Degumming, dewaxing and deacidification of rice bran oil-hexane miscella using ceramic membrane: Pilot plant study. J. Am. Oil Chem. 91, 1453-1460.

Rydberg J, Musikas C, Choppin GR. 1992. Principles and practices of solvent extraction. Marcel Dekker Inc., New York, USA.

Saravanan M, Bhosle BM, Subramanian R. 2006. Processing hexane-oil miscella using a nonporous polymeric composite membrane. J. Food Eng. 74, 529-535. http://dx.doi. org/10.1016/j.jfoodeng.2005.03.040

Subramanian R, Ichikawa S, Nakajima M, Kimura T, Maekawa T. 2001. Characterization of phospholipid reverse micelles in relation to membrane processing of vegetable oils. Eur. J. Lipid Sci. Technol. 103, 93-97.

Subramanian R, Nakajima M.1997. Membrane degumming of crude soybean and rapessed oils. J. Am. Oil Chem.74, 971-975.

Tsui EM, Cheryan M. 2004. Characteristics of nanofiltration membranes in aqueous ethanol. J. Membrane Sci. 237, 61-69. http://dx.doi.org/10.1016/j.memsci.2004.02.026.

Yang XJ, Livingston AG, Santos LF. 2001. Experimental observations of nanofiltration with organic solvents. $J$. Membrane Sci. 190, 45-55. http://dx.doi.org/10.1016/S03767388(01)00392-1. 